\title{
Calcium nitrate on growth and ornamental traits at salt-stressed condition in ornamental kale (Brassica oleracea L. var. Acephala)
}

\author{
Fazilet Parlakova Karagöz ${ }^{*} \odot$, Atilla Dursun ${ }^{1.2}$ ๑ \\ ${ }^{1}$ Atatürk University, Faculty of Agriculture, Department of Horticulture, Erzurum, Turkey \\ ${ }^{2}$ Kyrgyz-Turkish Manas University, Faculty of Agriculture, Department of Horticulture and Agronomy, Bishkek, Kyrgyzstan, Turkey
}

\begin{abstract}
Ornamental plants are used to improve the aestheticquality of urban and rural landscapes, recreational areas, interiorscapes and commercial sites. Any negative effects of salts on ornamental plant growth have to be taken into consideration mainly for their negative influences on aesthetic value of ornamental plants. The research was conducted to determine the effects of different concentrations of calcium nitrate on some stress parameters (i.e. leaf relative water content, chlorophyll, stomatal conductance, ion leakage in the leaf tissues) and some plant growth parameters (total leaf number, number of dried leaf, main stem diameter, plant crown diameter, plant height, fresh and dry weight of root) of ornamental kale (Brassica oleracea L. var. acephala) plant grown under saline conditions. Four doses of $\mathrm{NaCl}\left(\mathrm{NaCl}_{1}: 30, \mathrm{NaCl}_{2}: 60, \mathrm{NaCl}_{3}: 90, \mathrm{NaCl}_{4}: 120 \mathrm{mM}\right)$, three doses of $\mathrm{Ca}\left(\mathrm{NO}_{3}\right)_{2}\left(\mathrm{CaN}_{1}: 5, \mathrm{CaN}_{2}: 10, \mathrm{CaN}_{3}: 15 \mathrm{mM}\right)$, groups combined together in all doses of $\mathrm{NaCl}$ and $\mathrm{Ca}\left(\mathrm{NO}_{3}\right)_{2}$ and control $\left(\mathrm{NaCl}_{0}: 0+\mathrm{CaN}_{0}: 0\right)$ were applied into the pots with three replications. $\mathrm{Ca}\left(\mathrm{NO}_{3}\right)_{2}$ was applied to the leaf surface of the plants in the pots to be applied as $\mathrm{Ca}\left(\mathrm{NO}_{3}\right)_{2}$ spray. When the plants reached a certain maturity (two weeks after transfer to the pot), salt stress applications were started. $\mathrm{Ca}\left(\mathrm{NO}_{3}\right)_{2}$ treatments have applied after one week from salt stress applications. Calcium nitrate treatements applied under salt stress conditions had positive effects and increasing in effect on all parameters examined except for chlorophyll and ion leakage in leaf tissues of the plant. With increasing in calcium nitrate concentration, morphological and physiological characteristics of plants were observed increases in general. It was concluded that the increase of the number of leaves by $\mathrm{NaCl}_{2}+\mathrm{CaN}_{3}$ application can be minimized with $\mathrm{CaN}_{3}$ (with $15 \mathrm{mM} \mathrm{Ca}\left(\mathrm{NO}_{3}\right)_{2}$ ) stress caused by 60 $\mathrm{mM}$ salt concentration According to the results of the research, calcium nitrate applications can be recommended for ornamental kale plants grown under salt stress conditions especially limiting the negative effects of stress and to minimize such damage.
\end{abstract}

Keywords: salinity, $\mathrm{Ca}\left(\mathrm{NO}_{3}\right)_{2}$, aesthetic value, salt stress, ion leakage, ornamental plant.

\section{Resumo}

Nitrato de cálcio no crescimento e nas características ornamentais em condição de estresse salino em couve ornamental (Brassica oleracea L. var. Acephala)

As plantas ornamentais são utilizadas para melhorar a qualidade estética de paisagens urbanas e rurais, áreas de lazer, paisagens interiores e locais comerciais. Quaisquer efeitos negativos dos sais no crescimento das plantas ornamentais devem ser levados em consideração principalmente por suas influências negativas no valor estético das plantas ornamentais. A pesquisa foi conduzida para determinar os efeitos de diferentes concentrações de nitrato de cálcio em alguns parâmetros de estresse (ou seja, teor de água relativo à folha, clorofila, condutância estomática, perda iônica nos tecidos da folha) e alguns parâmetros de crescimento da planta (número total de folhas, número de folhas secas folha, diâmetro principal do caule, diâmetro da copa da planta, altura da planta, massa fresca e seca da raiz) de planta de couve ornamental (Brassica oleracea L. var. acephala) cultivada em condições salinas. Quatro doses de $\mathrm{NaCl}$ $\left(\mathrm{NaCl}_{1}: 30, \mathrm{NaCl}_{2}: 60, \mathrm{NaCl}_{3}: 90, \mathrm{NaCl}_{4}: 120 \mathrm{mM}\right)$, três doses de $\mathrm{Ca}\left(\mathrm{NO}_{3}\right)_{2}\left(\mathrm{CaN}_{1}: 5, \mathrm{CaN}_{2}: 10, \mathrm{CaN}_{3}: 15 \mathrm{mM}\right)$, grupos combinados em todas as doses de $\mathrm{NaCl}$ e Ca$\left(\mathrm{NO}_{3}\right)_{2}$ e controle $\left(\mathrm{NaCl}_{0}: 0+\mathrm{CaN}_{0}: 0\right)$ foram aplicadas nos vasos com três repetições. $\mathrm{O} \mathrm{Ca}\left(\mathrm{NO}_{3}\right)_{2}$ foi aplicado na superfície foliar das plantas nos vasos a serem aplicados como spray de $\mathrm{Ca}\left(\mathrm{NO}_{3}\right)_{2}$. Quando as plantas atingiram uma certa maturidade (duas semanas após a transferência para o vaso), as aplicações de estresse salino foram iniciadas. Tratamentos de $\mathrm{Ca}\left(\mathrm{NO}_{3}\right)_{2}$ foram aplicados após uma semana das aplicações de estresse salino. Tratamentos com nitrato de cálcio aplicados sob condições de estresse salino tiveram efeitos positivos e crescentes em efeito em todos os parâmetros examinados, exceto para clorofila e perda iônica nos tecidos foliares da planta. Com o aumento da concentração de nitrato de cálcio, as características morfológicas e fisiológicas das plantas foram observadas aumentos em geral. Concluiu-se que o aumento do número de folhas pela aplicação de $\mathrm{NaCl}_{2}+\mathrm{CaN}_{3}$ pode ser minimizado com estresse de $\mathrm{CaN}_{3}\left(\mathrm{com} 15 \mathrm{mM} \mathrm{Ca}\left(\mathrm{NO}_{3}\right)_{2}\right.$ ) causado pela concentração de sal $60 \mathrm{mM}$. De acordo com os resultados da pesquisa, aplicações de nitrato de cálcio podem ser recomendado para plantas ornamentais de couve cultivadas em condições de estresse salino, especialmente para limitar os efeitos negativos do estresse e minimizar tais danos.

Palavras-chave: salinidade, $\mathrm{Ca}\left(\mathrm{NO}_{3}\right)_{2}$, valor estético, estresse salino, perda iônica, plantas ornamentais.

"Corresponding author: f.parlakova@atauni.edu.tr 


\section{Introduction}

Salinity stress is an environmental stress factor in terms of culture plants and belongs to the chemical stress group. Growth medium is problem if containing salt causing many negative effect on plant. These negative effects can be listed as enzyme activation disorder, nutrient imbalance, membrane dysfunction, disruptions in the general metabolic process, osmotic incompatibility and imbalance in water intake, oxidative stress and general development insufficiency (Acosta-Motos et al., 2017; Yadav et al., 2019).

For agricultural crop plants, salt tolerance is generally assessed based on the growth or decrease in yield of certain plant parts such as seeds, roots, fruits or leaves (Xu and Mou, 2016; Yadav et al., 2019). However, aesthetic value is more important than that of growth rate for landscape plants (Cetin et al., 2018). Therefore, the visual quality is an important parameter to evaluate the salt tolerance of landscape plants.

Ornamental kale (Brassica oleracea L. var. acephala) is a popular ornamental plant cultivated worldwide owing to its variegated, colorful leaves (Ren et al., 2019) and strong resistance to cold. Ornamental kale is very closely related to cabbage, but it does not form a compact head. The ornamental kale appears to be the oldest type of Brassica (Dixon, 2017). Although there is little information about the salt tolerance of the ornamental kale, Malcolm and Smith (1971) put forward that the kale can be productive when watered with electrical conductivity in the range 2.3-5.5 $\mathrm{dS} \mathrm{m}^{-1}$.

It has been determined in some studies that compounds containing $\mathrm{Ca}, \mathrm{K}$ or $\mathrm{P}$ which are applied externally to the plants under salt stress were reduced the uptake by competing with $\mathrm{Na}$ in the leaves and roots of the plant. There are some studies in which the plant's capacity to resist stress was increased in $\mathrm{Ca}, \mathrm{K}$ and $\mathrm{P}$ ions reaching sufficient levels to withstand stress (Levent Tuna et al., 2007; Afzal et al., 2015; Sajyan et al., 2019; Kara et al., 2019; Zirek and Uzal, 2020). Calcium is considered to be the basic mineral nutrient for the growth and development of plants protecting the structural and functional integrity of plant membranes, regulating ion transport, stabilizing cell wall structures and controlling and selecting ion exchange behavior, as well as walling enzyme activities (Levent Tuna et al., 2007; Marschner, 2012; Bennett et al., 2020).

Recent studies have shown that calcium added to the saline solution was significantly improved plant species affected by high salinity (Levent Tuna et al., 2007; Tanveer et al., 2020). The aim of this study was to determine the negative effect of salt concentrations in the cultivation of ornamental cabbage in greenhouse conditions, and as a solution to salt stress, it was determined what change in direction of some stress parameters by applying of different concentrations of calcium nitrate.

\section{Materials and Methods}

Ornamental kale (Brassica oleracea L. var. acephala) 'Nagoya Red F1' seeds (seeds was obtained from a commercial company called Sakata Ornamentals) were planted in plug trays (molded plastic propagation trays with $1.5 \mathrm{~cm}^{3}$ inverted cone-shaped pockets), on 05 November 2017-2018. Trays were placed in a climate-controlled research greenhouse. Seedlings were planted in $500 \mathrm{cc}$ plastic pots filled with $2 / 3$ soil and $1 / 3$ peat mixture during the seedling period when they had 4-5 true leaves. A seedling was planted in each pot. The experiment was carried out in greenhouse conditions with mean air temperature of 25/17 $\pm 2{ }^{\circ} \mathrm{C}$ (day/night), relative air humidity of $50 \% \pm 10 \%$, in Department of Horticulture at Agriculture Faculty of Atatürk University, in Erzurum (Turkey).

Four doses of $\mathrm{NaCl}\left(\mathrm{NaCl}_{1}: 30, \mathrm{NaCl}_{2}: 60, \mathrm{NaCl}_{3}: 90\right.$, $\left.\mathrm{NaCl}_{4}: 120 \mathrm{mM}\right)$, three doses of $\mathrm{Ca}\left(\mathrm{NO}_{3}\right)_{2}\left(\mathrm{CaN}_{1}: 5, \mathrm{CaN}_{2}: 10\right.$, $\mathrm{CaN}_{3}: 15 \mathrm{mM}$ ), groups combined together in all doses of $\mathrm{NaCl}$ and $\mathrm{Ca}\left(\mathrm{NO}_{3}\right)_{2}\left(\mathrm{NaCl}_{1}+\mathrm{CaN}_{1}, \mathrm{NaCl}_{1}+\mathrm{CaN}_{2}, \mathrm{NaCl}_{1}+\mathrm{CaN}_{3}\right.$; $\mathrm{NaCl}_{2}+\mathrm{CaN}_{1}, \mathrm{NaCl}_{2}+\mathrm{CaN}_{2}, \mathrm{NaCl}_{2}+\mathrm{CaN}_{3} ; \mathrm{NaCl}_{3}+\mathrm{CaN}_{1}$, $\mathrm{NaCl}_{3}+\mathrm{CaN}_{2}, \mathrm{NaCl}_{3}+\mathrm{CaN}_{3} ; \mathrm{NaCl}_{4}+\mathrm{CaN}_{1}, \mathrm{NaCl}_{4}+\mathrm{CaN}_{2}$, $\left.\mathrm{NaCl}_{4}+\mathrm{CaN}_{3}\right)$ and control $\left(\mathrm{NaCl}_{0}: 0+\mathrm{CaN}_{0}: 0\right.$ ) (The method used by Ebert et al., 2002 was adapted) were applied into the pots with three replications. Each replication was formed from ten pots. Volume of the saline solution was given as irrigation water with $100-200 \mathrm{~mL}$ per pot (depending on plant growth) for salt pots to be applied. $\mathrm{Ca}\left(\mathrm{NO}_{3}\right)_{2}$ was applied to the leaf surface of the plants in the pots to be applied as $\mathrm{Ca}\left(\mathrm{NO}_{3}\right)_{2}$ spray. The volume of solution sprayed ranged from 5 to $50 \mathrm{~mL}$ per plant each time depending on plant development. When the plants reached a certain maturity (two weeks after transfer to the pot), salt stress applications were started. $\mathrm{Ca}\left(\mathrm{NO}_{3}\right)_{2}$ treatments have applied after one week from salt stress applications. No nutrition was applied and irrigation was carried out according to the irrigation needs of the plants during the experiment.

When physiological problems appeared in the plants, the experiment was terminated on the 45th day for the necessary analyzes. Total leaf number, number of dried leaf, main stem diameter, plant crown diameter, plant height, fresh and dry weight of root, leaf chlorophyll (using chlorophyll meter (SPAD-502, Konica Minolta Sensing, Inc., Japan)), stomatal conductance (using a porometer (Sc 1 Porometer, Decagon Devices Inc., WA, USA)) of the seedlings were determined at the end of the study. In addition, the relative (proportional) water content (RWC) and ion leakage in the leaf tissues were determined according to the method of Larbi et al. (2020).

The data obtained from the study were subjected to variance analysis according to the Experimental Design of Random Parcels established in factorial order. The results were evaluated by using the "SPSS Statistics for Windows 20.0" statistical program. The difference between the treatments was demonstrated with Duncan test at 0.05 Significance Level. 


\section{Results and Discussion}

Effects of $\mathrm{NaCl}$ and calcium treatments on the growth criteria and comparison of the means according to Duncan test are given in Table 1. Calcium application significantly increased in total leaf number, plant crown diameter, plant height, leaf chlorophyll, Fresh and dry weight of root and this increase diminished with increasing in $\mathrm{NaCl}$ doses.

Table 1. The effects of $\mathrm{NaCl}$ and calcium nitrate treatments on growth criteria.

\begin{tabular}{|c|c|c|c|c|c|}
\hline Treatments & $\begin{array}{l}\text { Total leaf no. } \\
\text { (per plant) }\end{array}$ & $\begin{array}{l}\text { Number of dried } \\
\text { leaf (per plant) }\end{array}$ & $\begin{array}{c}\text { Main stem } \\
\text { diameter }(\mathbf{m m})\end{array}$ & $\begin{array}{c}\text { Plant crown } \\
\text { diameter }(\mathrm{cm})\end{array}$ & Plant height $(\mathrm{cm})$ \\
\hline $\mathrm{NaCl}_{0}+\mathrm{CaN}_{0}$ & $6.67 \pm 0.58 \mathrm{e}-\mathrm{g} * * *$ & $9.67 \pm 0.58 \mathrm{a}^{* * *}$ & $3.83 \pm 0.13 \mathrm{ab}^{* * *}$ & $14.30 \pm 0.97 \mathrm{~b}^{* *}$ & $10.62 \pm 0.66 \mathrm{a}-\mathrm{c}^{*}$ \\
\hline $\mathrm{NaCl}_{1}$ & $6.67 \pm 0.58 \mathrm{e}-\mathrm{g}$ & $9.33 \pm 0.58 \mathrm{ab}$ & $3.20 \pm 0.07$ e-h & $10.87 \pm 0.81 \mathrm{gh}$ & $9.77 \pm 0.59$ b-e \\
\hline $\mathrm{NaCl}_{2}$ & $5.67 \pm 0.58 \mathrm{eg}$ & $8.67 \pm 2.08 \mathrm{ab}$ & $3.29 \pm 0.04 \mathrm{~d}-\mathrm{g}$ & $10.92 \pm 0.60 \mathrm{gh}$ & $9.83 \pm 0.90 \mathrm{~b}-\mathrm{e}$ \\
\hline $\mathrm{NaCl}_{3}$ & $4.67 \pm 0.58 \mathrm{~g}$ & $8.00 \pm 1.00 b c$ & $3.38 \pm 0.12 \mathrm{de}$ & $11.13 \pm 0.78 \mathrm{f}-\mathrm{h}$ & $8.58 \pm 1.32 \mathrm{e}$ \\
\hline $\mathrm{NaCl}_{4}$ & $5.33 \pm 1.53 \mathrm{fg}$ & $9.00 \pm 1.00 \mathrm{ab}$ & $2.85 \pm 0.131$ & $11.38 \pm 0.43 \mathrm{~d}-\mathrm{h}$ & $8.87 \pm 0.99 \mathrm{de}$ \\
\hline $\mathrm{CaN}_{1}$ & $11.00 \pm 1.00 \mathrm{a}-\mathrm{c}$ & $4.33 \pm 0.58 \mathrm{f}$ & $3.73 \pm 0.28 \mathrm{~b}$ & $14.99 \pm 0.80 \mathrm{ab}$ & $9.63 \pm 1.32 \mathrm{~b}-\mathrm{e}$ \\
\hline $\mathrm{CaN}_{2}$ & $12.33 \pm 0.58 \mathrm{ab}$ & $6.00 \pm 1.00 \mathrm{de}$ & $4.04 \pm 0.06 \mathrm{a}$ & $14.40 \pm 0.68 \mathrm{~b}$ & $11.35 \pm 0.76 \mathrm{ab}$ \\
\hline $\mathrm{CaN}_{3}$ & $13.00 \pm 1.00 \mathrm{a}$ & $5.67 \pm 0.58 \mathrm{~d}-\mathrm{f}$ & $3.82 \pm 0.10 \mathrm{ab}$ & $15.82 \pm 0.75 \mathrm{a}$ & $11.76 \pm 0.52 \mathrm{a}$ \\
\hline $\mathrm{NaCl}_{1}+\mathrm{CaN}_{1}$ & $8.33 \pm 0.58 \mathrm{de}$ & $8.33 \pm 0.58 \mathrm{ab}$ & $3.84 \pm 0.10 \mathrm{ab}$ & $12.37 \pm 0.55 \mathrm{c}-\mathrm{e}$ & $10.55 \pm 0.59 a-d$ \\
\hline $\mathrm{NaCl}_{1}+\mathrm{CaN}_{2}$ & $9.67 \pm 0.58 \mathrm{~cd}$ & $5.33 \pm 0.58 \mathrm{~d}-\mathrm{f}$ & $3.87 \pm 0.13 \mathrm{ab}$ & $11.89 \pm 0.46 \mathrm{c}-\mathrm{g}$ & $10.03 \pm 0.71 \mathrm{~b}-\mathrm{e}$ \\
\hline $\mathrm{NaCl}_{1}+\mathrm{CaN}_{3}$ & $10.00 \pm 1.00 \mathrm{~b}-\mathrm{d}$ & $4.33 \pm 0.58 \mathrm{f}$ & $3.86 \pm 0.13 \mathrm{ab}$ & $12.57 \pm 0.43 \mathrm{~cd}$ & $9.42 \pm 0.42 \mathrm{c}-\mathrm{e}$ \\
\hline $\mathrm{NaCl}_{2}+\mathrm{CaN}_{1}$ & $8.00 \pm 1.00 \mathrm{de}$ & $8.00 \pm 1.00 \mathrm{bc}$ & $3.12 \pm 0.10 \mathrm{f}-\mathrm{h}$ & $11.20 \pm 0.27 \mathrm{e}-\mathrm{h}$ & $9.61 \pm 1.12 \mathrm{c}-\mathrm{e}$ \\
\hline $\mathrm{NaCl}_{2}+\mathrm{CaN}_{2}$ & $5.67 \pm 4.93 \mathrm{e}-\mathrm{g}$ & $5.00 \pm 1.00 \mathrm{ef}$ & $3.09 \pm 0.10 \mathrm{gh}$ & $10.50 \pm 0.18 \mathrm{~h}$ & $9.68 \pm 0.76 b-e$ \\
\hline $\mathrm{NaCl}_{2}+\mathrm{CaN}_{3}$ & $11.00 \pm 1.00 \mathrm{a}-\mathrm{c}$ & $6.67 \pm 0.58 \mathrm{~cd}$ & $3.23 \pm 0.15 \mathrm{~d}-\mathrm{h}$ & $10.89 \pm 0.81 \mathrm{gh}$ & $10.17 \pm 0.27$ a-e \\
\hline $\mathrm{NaCl}_{3}+\mathrm{CaN}_{1}$ & $8.33 \pm 0.58 \mathrm{de}$ & $8.67 \pm 0.58 \mathrm{ab}$ & $3.63 \pm 0.16 \mathrm{bc}$ & $12.65 \pm 0.59 \mathrm{c}$ & $9.68 \pm 0.63 \mathrm{~b}-\mathrm{e}$ \\
\hline $\mathrm{NaCl}_{3}+\mathrm{CaN}_{2}$ & $9.67 \pm 0.58 \mathrm{~cd}$ & $5.67 \pm 0.58 \mathrm{~d}-\mathrm{f}$ & $3.47 \pm 0.27 \mathrm{~cd}$ & $12.07 \pm 1.11 \mathrm{c}-\mathrm{g}$ & $9.27 \pm 1.09 \mathrm{c}-\mathrm{e}$ \\
\hline $\mathrm{NaCl}_{3}+\mathrm{CaN}_{3}$ & $10.00 \pm 1.00 \mathrm{~b}-\mathrm{d}$ & $6.67 \pm 0.58 \mathrm{~cd}$ & $3.34 \pm 0.07 \mathrm{~d}-\mathrm{f}$ & $12.10 \pm 0.35 \mathrm{c}-\mathrm{g}$ & $9.53 \pm 1.74 \mathrm{c}-\mathrm{e}$ \\
\hline $\mathrm{NaCl}_{4}+\mathrm{CaN}_{1}$ & $7.00 \pm 1.00 \mathrm{e}-\mathrm{g}$ & $5.67 \pm 0.58 \mathrm{~d}-\mathrm{f}$ & $2.79 \pm 0.121$ & $11.92 \pm 0.42 \mathrm{c}-\mathrm{g}$ & $10.72 \pm 0.72 \mathrm{a}-\mathrm{c}$ \\
\hline $\mathrm{NaCl}_{4}+\mathrm{CaN}_{2}$ & $7.67 \pm 0.58 \mathrm{~d}-\mathrm{f}$ & $5.33 \pm 0.58 \mathrm{~d}-\mathrm{f}$ & $3.00 \pm 0.03 \mathrm{~h} 1$ & $12.16 \pm 0.39 c-f$ & $9.84 \pm 0.38 \mathrm{~b}-\mathrm{e}$ \\
\hline $\mathrm{NaCl}_{4}+\mathrm{CaN}_{3}$ & $7.00 \pm 1.00 \mathrm{e}-\mathrm{g}$ & $4.67 \pm 0.58$ ef & $3.19 \pm 0.05$ e-h & $10.94 \pm 0.44 \mathrm{gh}$ & $9.69 \pm 0.49 \mathrm{~b}-\mathrm{e}$ \\
\hline Mean & $8.38 \pm 2.60$ & $6.75 \pm 1.88$ & $3.43 \pm 0.38$ & $12.25 \pm 1.57$ & $9.93 \pm 1.04$ \\
\hline
\end{tabular}

${ }^{*} p \leq 0.05 ; * * p \leq 0.01 ; * * * \leq \leq 0.001$; ns: not significant $(p \geq 0.05)$. The numbers in one column having the same letter are not significantly different.

When results of the total leaf number were evaluated in the study, significant differences were found as expected depending on the salt levels (Hoang et al., 2020). The highest total number of leaves was in $\mathrm{CaN}_{3}$ application and the total number of leaves increased by $94.90 \%$ comparing to the control. $\mathrm{CaN}_{3}$ treatment was in the same statistical group with lower doses of calcium treatments $\left(\mathrm{CaN}_{1}\right.$ and $\left.\mathrm{CaN}_{2}\right)$ and $\mathrm{NaCl}_{2}+\mathrm{CaN}_{3}$ treatment (Table 1). The $\mathrm{NaCl}_{2}+\mathrm{CaN}_{3}$ treatment was increased in the total number of leaves by $94.00 \%$ when compared the $\mathrm{NaCl}_{2}$ treatment. This result is important in terms of emphasizing the ability of calcium applications to reduce adverse effects in saline conditions. The result is shown in parallel with many studies (Türkmen et al., 2002; Yakıt and Tuna, 2006; Durukan and Demirbas, 2018; Larbi et al., 2020).

One of the changes caused by salt stress in plants is yellowing and drying, starting with tissues such as leaves and the tip of the shoot then spreading to the plant's shoots. These yellowing and drying are symptoms resulting from the breakdown of chloroplasts and chlorophyll (Abid et al., 2020). By making use of these symptoms, it is possible to determine to what extent the plant is affected by salt stress. In general, ornamental plants and ornamental kale cultivation, leaf density, color and pot filling volume parameters are important aesthetic criteria. In the present study, the maximum number of dry leaves determined (9.67 number per plant) is the control. Control treatment were in the same statistical group with $\mathrm{NaCl}_{1}, \mathrm{NaCl}_{2}, \mathrm{NaCl}_{4}$. $\mathrm{NaCl}_{1}+\mathrm{CaN}_{1}$ and $\mathrm{NaCl}_{3}+\mathrm{CaN}_{1}$. The minimum number of dried leaves was obtained from $\mathrm{CaN}_{1}$ and $\mathrm{NaCl}_{1}+\mathrm{CaN}_{3}$ (4.33 number per plant) (Table 1). As a result of less dried leaves in $\mathrm{NaCl}_{1}+\mathrm{CaN}_{3}$ application, it was concluded that the negative effect of $30 \mathrm{mM}$ salt dose could be reduced with $15 \mathrm{mM} \mathrm{Ca}\left(\mathrm{NO}_{3}\right)_{2}$ dose.

The highest main stem diameter was determined in $\mathrm{CaN}_{2}$. Main stem diameter was decreased by $25.59 \%$ in $\mathrm{NaCl}_{4}$ application, which is the highest salt dose according to control treatment. This result highlighted once again that increasing in salt concentration in growing medium decreases plant growth. Salt stress often negatively affects on the growth attributes of kale plants, due to 
the unfavorable conditions for physiological processes such as photosynthesis, accumulation of compatible solutes, nutrient homeostasis and activities of antioxidant enzymes (Yu et al., 2019). Patel et al. (2011) reported that exogenously supplied calcium alleviated deleterious effects of $\mathrm{Na}^{+}$on the physiological performance of hydroponically grown plants, the application of $\mathrm{Ca}\left(\mathrm{NO}_{3}\right)_{2}$ ameliorated the capacity of root for nutrient uptake and water.

In present study, salt stress induced by all $\mathrm{NaCl}$ doses significantly inhibited the plant crown diameter of kale plants. Borlu et al. (2018) reported that the germination percentage, vigor index, seedling height, root length were decreased significantly with increasing salinity. Ozturk (2002) reported that salt negatively affected on plant height values when salt water applied to eggplant plant. Kozminska et al. (2017) stated that plant height of Calendula officinalis L. decreased under salt stress. However, the application of $\mathrm{Ca}\left(\mathrm{NO}_{3}\right)_{2}$ could effectively alleviate this phenomenon in our study. This feature was proved by reductions in the plant height and plant crown diameter (Table 1).

In the study, it was determined that calcium applications generally had positive effects on chlorophyll amounts, and maximum the leaf chlorophyll content was obtained from $\mathrm{CaN}_{3}$ treatment. When only calcium treated plant groups and salt treated plant groups are compared, it was concluded that the salt reduced the chlorophyll content. The decrease in chlorophyll levels in salt stressed plants has been considered as a typical symptom of oxidative stress (Elsheery and Cao, 2008; Taïbi et al., 2016). This is due to the disruption of general metabolic activities under salt stress of plants and negatively affected on chlorophyll activation (Turan and Aydın, 2005; Bayat et al., 2012; Kozminska et al., 2017). Yakit and Tuna (2006) reported that $\mathrm{Ca}, \mathrm{K}$ and $\mathrm{Mg}$ compounds added to the nutrient solution were alleviated the negative effects on chlorophyll of $\mathrm{NaCl}$ in their study. Negative relationship between salt and chlorophyll was also highlighted by Kuşvuran et al. (2008), Yakıt and Tuna (2006) and Kozminska et al. (2017). These results coincide with the findings of the studies reported above.

The stoma plays a key role in regulating the gas exchange on the leaf surface (Lawson, 2009). Plants are constantly exposed to environmental stress conditions and have developed a range of mechanisms that regulate stoma behavior in response to this stress (Zhu et al., 2018). It is known that high salinity decreases the stoma conductivity of adaxial and abaxial leaf surfaces (Piñero et al., 2014; GarcíaCaparrós and Lao, 2018). In the present study, the highest stomal conductivity was determined in the control application while stomal conductivity was low in all treatments except control and $\mathrm{Ca}\left(\mathrm{NO}_{3}\right)_{2}$ treatments (Table 2).

Table 2. The effects of $\mathrm{NaCl}$ and calcium nitrate treatments on some physiological parameters, fresh and dry weight of root.

\begin{tabular}{|c|c|c|c|c|c|c|}
\hline Treatments & Leaf chlorophyll & $\begin{array}{c}\text { Stomatal } \\
\text { conductance }\end{array}$ & RWC (\%) & $\begin{array}{l}\text { Relative ion } \\
\text { leakage (\%) }\end{array}$ & $\begin{array}{c}\text { Fresh weight of } \\
\operatorname{root}(\mathrm{g})\end{array}$ & $\begin{array}{c}\text { Dry weight } \\
\text { of } \operatorname{root}(g)\end{array}$ \\
\hline $\mathrm{NaCl}_{0}+\mathrm{CaN}_{0}$ & $38.53 \pm 0.95 \mathrm{~h}^{* * *}$ & $82.96 \pm 3.15 \mathrm{a}^{* * *}$ & $47.69 \pm 26.46^{\mathrm{ns}}$ & $101.70 \pm 0.99 \mathrm{j}^{* * *}$ & $0.74 \pm 0.55 \mathrm{e}-\mathrm{g} * * *$ & $\begin{array}{c}0.24 \pm 0.04 \\
\mathrm{c} * * *\end{array}$ \\
\hline $\mathrm{NaCl}_{1}$ & $49.27 \pm 0.35 \mathrm{~d}-\mathrm{f}$ & $24.20 \pm 0.80 \mathrm{e}$ & $52.44 \pm 30.06$ & $109.31 \pm 0.63 \mathrm{~cd}$ & $0.88 \pm 0.03 \mathrm{~d}-\mathrm{g}$ & $0.19 \pm 0.01 \mathrm{c}$ \\
\hline $\mathrm{NaCl}_{2}$ & $44.70 \pm 3.12 \mathrm{~g}$ & $22.46 \pm 2.17$ ef & $27.97 \pm 24.88$ & $111.45 \pm 1.09 \mathrm{c}$ & $1.20 \pm 0.06 \mathrm{~cd}$ & $0.16 \pm 0.02 \mathrm{c}$ \\
\hline $\mathrm{NaCl}_{3}$ & $45.27 \pm 0.64 \mathrm{~g}$ & $18.69 \pm 0.28 \mathrm{f}-\mathrm{h}$ & $44.40 \pm 10.08$ & $114.96 \pm 3.04 \mathrm{~b}$ & $0.98 \pm 0.03 \mathrm{~d}-\mathrm{g}$ & $0.27 \pm 0.08 \mathrm{c}$ \\
\hline $\mathrm{NaCl}_{4}$ & $46.37 \pm 2.13 \mathrm{e}-\mathrm{g}$ & $18.69 \pm 0.28 \mathrm{f}-\mathrm{h}$ & $46.43 \pm 4.04$ & $119.23 \pm 1.02 \mathrm{a}$ & $0.81 \pm 0.05 \mathrm{e}-\mathrm{g}$ & $0.16 \pm 0.05 \mathrm{c}$ \\
\hline $\mathrm{CaN}_{1}$ & $45.54 \pm 1.04 \mathrm{fg}$ & $63.08 \pm 0.92 \mathrm{c}$ & $47.80 \pm 24.04$ & $103.37 \pm 1.24 \mathrm{~g}-\mathrm{j}$ & $1.36 \pm 0.54 \mathrm{bc}$ & $0.44 \pm 0.30 \mathrm{~b}$ \\
\hline $\mathrm{CaN}_{2}$ & $58.86 \pm 5.29 \mathrm{ab}$ & $65.49 \pm 5.06 \mathrm{c}$ & $53.93 \pm 13.32$ & $105.79 \pm 1.14$ e-h & $1.66 \pm 0.11 \mathrm{ab}$ & $0.83 \pm 0.04 \mathrm{a}$ \\
\hline $\mathrm{CaN}_{3}$ & $60.79 \pm 5.27 \mathrm{a}$ & $78.89 \pm 6.46 \mathrm{~b}$ & $47.39 \pm 20.88$ & $109.89 \pm 2.96 \mathrm{~cd}$ & $1.88 \pm 0.11 \mathrm{a}$ & $0.86 \pm 0.11 \mathrm{a}$ \\
\hline $\mathrm{NaCl}_{1}+\mathrm{CaN}_{1}$ & $52.02 \pm 0.30 \mathrm{~cd}$ & $22.21 \pm 1.35$ ef & $58.01 \pm 6.77$ & $105.02 \pm 0.57 \mathrm{f}-1$ & $0.90 \pm 0.02 \mathrm{~d}-\mathrm{g}$ & $0.25 \pm 0.06 \mathrm{c}$ \\
\hline $\mathrm{NaCl}_{1}+\mathrm{CaN}_{2}$ & $48.23 \pm 0.72 \mathrm{~d}-\mathrm{g}$ & $15.34 \pm 0.61 \mathrm{~h}-\mathrm{k}$ & $43.56 \pm 11.07$ & $107.84 \pm 1.82$ d-f & $1.10 \pm 0.07 \mathrm{c}-\mathrm{e}$ & $0.23 \pm 0.07 \mathrm{c}$ \\
\hline $\mathrm{NaCl}_{1}+\mathrm{CaN}_{3}$ & $55.80 \pm 0.81 \mathrm{bc}$ & $16.32 \pm 1.14 \mathrm{~g}-\mathrm{j}$ & $48.51 \pm 4.44$ & $106.18 v 0.62 \mathrm{e}-\mathrm{g}$ & $0.98 \pm 0.03 \mathrm{~d}-\mathrm{g}$ & $0.26 \pm 0.08 \mathrm{c}$ \\
\hline $\mathrm{NaCl}_{2}+\mathrm{CaN}_{1}$ & $46.85 \pm 0.95 \mathrm{e}-\mathrm{g}$ & $19.84 \pm 0.27 \mathrm{fg}$ & $55.58 \pm 10.33$ & $103.79 \pm 3.44 \mathrm{~g}-\mathrm{j}$ & $0.89 \pm 0.02 \mathrm{~d}-\mathrm{g}$ & $0.21 \pm 0.05 \mathrm{c}$ \\
\hline $\mathrm{NaCl}_{2}+\mathrm{CaN}_{2}$ & $49.85 \pm 0.40 \mathrm{de}$ & $19.56 \pm 0.99 \mathrm{f}-\mathrm{h}$ & $42.30 \pm 6.02$ & $109.68 \pm 2.15 \mathrm{~cd}$ & $0.62 \pm 0.08 \mathrm{~g}$ & $0.14 \pm 0.04 \mathrm{c}$ \\
\hline $\mathrm{NaCl}_{2}+\mathrm{CaN}_{3}$ & $55.07 \pm 1.75 \mathrm{bc}$ & $36.86 \pm 3.12 \mathrm{~d}$ & $27.64 \pm 35.26$ & $108.27 \pm 1.79 \mathrm{de}$ & $1.03 \pm 0.05 \mathrm{c}-\mathrm{f}$ & $0.24 \pm 0.05 \mathrm{c}$ \\
\hline $\mathrm{NaCl}_{3}+\mathrm{CaN}_{1}$ & $55.34 \pm 0.71 \mathrm{bc}$ & $11.82 \pm 0.56 \mathrm{kl}$ & $49.80 \pm 0.86$ & $105.47 \pm 0.82 \mathrm{e}-1$ & $0.86 \pm 0.12 \mathrm{~d}-\mathrm{g}$ & $0.21 \pm 0.04 \mathrm{c}$ \\
\hline $\mathrm{NaCl}_{3}+\mathrm{CaN}_{2}$ & $55.43 \pm 1.38 \mathrm{bc}$ & $11.44 \pm 0.57 \mathrm{kl}$ & $48.24 \pm 3.45$ & $102.64 \pm 0.14 \mathrm{ij}$ & $1.06 \pm 0.08 \mathrm{c}-\mathrm{f}$ & $0.25 \pm 0.03 \mathrm{c}$ \\
\hline $\mathrm{NaCl}_{3}+\mathrm{CaN}_{3}$ & $55.17 \pm 0.75 \mathrm{bc}$ & $9.32 \pm 0.371$ & $43.31 \pm 40.21$ & $109.58 \pm 0.63 \mathrm{~cd}$ & $0.92 \pm 0.08 \mathrm{~d}-\mathrm{g}$ & $0.28 \pm 0.07 \mathrm{c}$ \\
\hline $\mathrm{NaCl}_{4}+\mathrm{CaN}_{1}$ & $56.71 \pm 0.31 \mathrm{~b}$ & $17.81 \pm 2.11 \mathrm{~g}-1$ & $43.13 \pm 8.55$ & $106.27 \pm 1.44 \mathrm{e}-\mathrm{g}$ & $0.72 \pm 0.06 \mathrm{fg}$ & $0.13 \pm 0.04 \mathrm{c}$ \\
\hline $\mathrm{NaCl}_{4}+\mathrm{CaN}_{2}$ & $49.73 \pm 0.53 \mathrm{de}$ & $13.88 \pm 0.791-\mathrm{k}$ & $41.13 \pm 14.65$ & $103.51 \pm 0.74 \mathrm{~g}-\mathrm{j}$ & $0.87 \pm 0.10 \mathrm{~d}-\mathrm{g}$ & $0.24 \pm 0.08 \mathrm{c}$ \\
\hline $\mathrm{NaCl}_{4}+\mathrm{CaN}_{3}$ & $50.70 \pm 1.48 \mathrm{~d}$ & $13.28 \pm 0.78 \mathrm{j}-1$ & $52.00 \pm 9.23$ & $102.94 \pm 0.67 \mathrm{~h}-\mathrm{j}$ & $0.73 \pm 0.08 \mathrm{fg}$ & $0.13 \pm 0.04 \mathrm{c}$ \\
\hline Mean & $51.01 \pm 5.76$ & $29.11 \pm 23.06$ & $46.06 \pm 17.28$ & $107.34 \pm 4.53$ & $1.01 \pm 0.35$ & $0.29 \pm 0.21$ \\
\hline Mean & 8. & 60 & & .38 & .57 & \pm 1.04 \\
\hline
\end{tabular}

" $p \leq 0.05 ; * * p \leq 0.01 ; * * * p \leq 0.001$; ns: not significant $(p \geq 0.05)$. The numbers in one column having the same letter are not significantly different. 
Stomal closure is one of the fastest responses to salinity (Liu et al., 2017; García-Caparrós and Lao, 2018) and the stoma closure response is believed to be crucial to minimize plant water loss under hyperosmotic conditions in the plant rhizosphere (Shabala and Pottosin,, 2014; Reef and Lovelock 2015). Reducing stomatal density is another way to optimize the balance between leaf water loss and $\mathrm{CO}_{2}$ assimilation. However, this strategy has a cost because the reduction in stomata will reduce photosynthesis, therebyplant biomass and yield will reduce (Liu et al., 2017).

As the salt concentration in the soil increases, the osmotic pressure increases and the water uptake of the plant from the soil becomes more difficult and the leaf relative water content values decrease. As a result of all these, plant growth slows down and even stops at advanced stages (Kanber et al., 1992; Jan et al., 2016). In the research, it was observed that the decrease effects expected in salt applications of leaf proportional moisture content values changed with calcium applications as slight increases. However, Table 2 shows that these increases are not statistically significant at $p<0.05$ level.

An indicator of membrane damage caused by salinity is the ion leakage state. Chlorine ions $\left(\mathrm{Cl}^{-}\right)$formed by $\mathrm{NaCl}$ molecules ionization deposited on the cell membrane in the presence salt stress rapidly drop $\mathrm{pH}$; this situation results in the breaking of hydrogen bonds of membrane protein and is caused to disperse into the environment, ions such as $\mathrm{K}^{+}$and $\mathrm{Ca}^{++}$from protein pump (Avcioğlu et al., 2003). This leads to deterioration of membrane integrity and ion leakage (Larbi et al., 2020). Briefly, the increase in the amount of ion leakage is an indication that the plant is damaged more than stress. In the present study, it was determined that the membrane permeability due to cell integrity disruption in the plants treated with the highest salt concentration $\left(\mathrm{NaCl}_{4}\right)$ was significantly increased in comparing to the control plants (Table 2). There are many research results related to increasing in membrane permeability in plants under salt stress (Karray-Bouraoui et al., 2009; Houimli et al., 2010; Larbi et al., 2020). It is thought that calcium help protect the membrane integrity by reducing the membrane permeability in plants under salt stress with $\mathrm{Ca}\left(\mathrm{NO}_{3}\right)_{2}$ applications. The results of this study can also be explained with this statement.

At the end of the study, the highest fresh and dry weight of root were determined in $\mathrm{CaN}_{2}$ and $\mathrm{CaN}_{3}$ treatments. While amount of root fresh weight obtained from $\mathrm{CaN}_{3}$ treatment was supplied an increase of $60.64 \%$ according to control while amount of root dry weight obtained from the same treatment was supplied an increase of $72.09 \%$ (Table 2). Ashraf et al. (2003) stated that the dry weight of okra root was negatively affected by result of salt treatment.
Borlu et al. (2018) reported that the increase in the levels of salinity, resulted reduced dry weight of wheat cultivars. Yildiz and Terzi (2011), Khan et al. (2013) stated that there was a decrease in root dry weight due to salt stress. The findings of Yildiz and Terzi (2011) and Khan et al. (2013) were supported the findings of root dry weight obtained in present study.

\section{Conclusions}

When all the results obtained from the study are evaluated together, it is seen that Ornamental kale (Brassica oleracea L. var. Acephala) can be cultivated under salt stress conditions. However, it was determined that salt stress was decreased in the values of some plant growth and physiological parameters such as total leaf number, main stem diameter, plant crown diameter, plant height, fresh and dry weight of root, chlorophyll and stomal conductivity. It was determined that salt stress was caused increases in parameters such as the number of dried leaves and ion leakage leaf tissues. Calcium nitrate treatements treated under salt stress conditions had positive and increasing effect on all parameters examined except chlorophyll and ion leakage in leaf tissues of the plant. With increasing calcium nitrate concentration, morphological and physiological characteristics of plants were high in general. The highest total number of leaves was determined in $\mathrm{CaN}_{3}$ application, and the number of leaves was also increased in other calcium doses. It was concluded that the increase of the number of leaves by $\mathrm{NaCl}_{2}+\mathrm{CaN}_{3}$ application can be minimized with $\mathrm{CaN}_{3}$ (with $15 \mathrm{mM} \mathrm{Ca}$ $\left.\left(\mathrm{NO}_{3}\right)_{2}\right)$ stress caused by $60 \mathrm{mM}$ salt concentration. Thus, in this negative condition, the continuity of the aesthetic feature of ornamental kale will be provided. Careful selection of calcium application doses is necessary to improve long-term yield and quality characteristics. As a matter of fact, $\mathrm{CaN}_{3}$ application had positive effects on stress parameters in this study. It would be useful to consider higher concentrations in future studies. According to the results of the research, calcium nitrate applications can be recommended for ornamental kale plants grown under salt stress conditions especially limiting the negative effects of stress and to minimize such damage.

\section{Author Contribution}

F.P.K.: Installation of the experiment, analysis and collect of data, preparation of the manuscript. Collaboration in the conducted of the experiment. Creation idea, preparation of the manuscript, research orientation, suggestions and ideas A.D.: Installation of the experiment, conduction, preparation of the manuscript. Creation idea, preparation of the manuscript, research orientation, suggestions and ideas. 


\section{References}

ABID, M.; ZHANG, Y.J.; Lİ, Z.; BAİ, D.F.; ZHONG, Y.P.; FANG, J.B. Effect of salt stress on growth, physiological and biochemical characters of Four kiwifruit genotypes. Scientia Horticulturae, v.271, p.109473, 2020. https:// doi.org/10.1016/j.scienta.2020.109473

ACOSTA-MOTOS, J.R.; ORTUÑO, M.F.; BERNALVICENTE, A.; DİAZ-VIVANCOS, P.; SANCHEZBLANCO, M.J.; HERNANDEZ, J.A. Plant responses to salt stress: adaptive mechanisms. Agronomy, v.7, n.1, 18, 2017. https://doi.org/10.3390/agronomy7010018

AFZAL, I.; HUSSAIN, B.; BASRA, S.M.A.; ULLAH.; S.H, SHAKEEL, Q.; KAMRAN, M. Foliar application of potassium improves fruit quality and yield of tomato plants. Acta Scientiarum Polonorum Hortorum Cultus, v.14, n.1, 3-13, 2015.

ASHRAF, M.; ARFAN, M.; AHMAD, A. Salt tolerance in okra: ion relations and gas exchange characteristics. Journal of Plant Nutrition v.26, n.1, 63-79, 2003.

AVCIOĞLU, R.; DEMIROĞLU, G.; KHALVATİ, M.A.; GEREN, H. Effects of osmotic pressure on early growing stages of some crop plants 11. proline, chlorophile accumulation and membrane integrity. Journal of Agriculture Faculty of Ege University, v.40, n.2, 9-16, 2003.

BAYAT, H.; ALIREZAİE, M.; NEAMATI, H. Impact of exogenous salicylic acid on growth and ornamental characteristics of calendula (Calendula officinalis L.) under salinity stress. Journal of Stress Physiology \& Biochemistry v.8, n.1, 258-267, 2012.

BENNETT, K.; JENT, J.; SAMARAKOON, U.C.; SCHNABEL, G.; FAUST, J.E. Reduction of Botrytis cinerea infection on petunia flowers following calcium spray applications. HortScience, v.55, n.2, 188-191, 2020.

BORLU, H.O.; CELIKTAS, V.; DUZENLİ, S.; HOSSAIN, A.; EL SABAGH, A. Germination and early seedling growth of five durum wheat cultivars (Triticum durum desf.) is affected by different levels of salinity. Fresenius Environmental Bulletin, v.27, n.11, 7746-7757, 2018.

CETIN, M.; SEVIK, H.; YİGIT, N.; OZEL, H.B.; ARİCAK, B.; VAROL, T. The variable of leaf micromorphogical characters on grown in distinct climate conditions in some landscape plants. Fresenius Environmental Bulletin, v.27, n.5, 3206-3211, 2018.

DIXON, G.R. The origins of edible brassicas. Plantsman, v.16, n.3, 180-185, 2017.

DURUKAN, H.; DEMIRBAS, A. The effects of different salt doses on yield and nutrient uptake of tomato plant. Scientific Papers-Series A-Agronomy, v.61, 71-76, 2018.
EBERT, G.; EBERLE, J.; ALİ-DINAR, H.; LÜDDERS, P. Ameliorating effects of $\mathrm{Ca}\left(\mathrm{NO}_{3}\right)_{2}$ on growth, mineral uptake and photosynthesis of $\mathrm{NaCl}$-stressed guava seedlings (Psidium guajava L.). Scientia Horticulturae, v.93, n.2, 125-135, 2002.

ELSHEERY, N.I.; CAO, K.F. Gas exchange, chlorophyllfluorescence, and osmotic adjust-ment in two mango cultivars under drought stress. Acta Physiologiae Plantarum, v.30, 769-777, 2008.

GARCÍA-CAPARRÓS, P.; LAO, M.T. The effects of salt stress on ornamental plants and integrative cultivation practices. Scientia Horticulturae, v.240, 430-439, 2018.

HOANG, L.H.; DE GUZMAN, C.C.; CADİZ, N.M.; TRAN, D.H. Physiological and phytochemical responses of red amaranth (Amaranthus tricolor L.) and green amaranth (Amaranthus dubius L.) to different salinity levels. Legume Research-An International Journal, v.43, n.2, 206-211, 2020.

HOUIMLİ, S.M.; DENDEN, M.; MOUHANDES, B.D. Effects of 24-Epibrassinolide on growth, chlorophyll, electrolyte leakage and proline by pepper plants under $\mathrm{NaCl}$-stress. EurAsian Journal of BioSciences, v.4, 96104, 2010.

JAN, S.A.; SHINWARI, Z.K.; RABBANI, M.A. Agromorphological and physiological responses of Brassica rapa ecotypes to salt stress. Pakistan Journal of Botany, v.48, n.4, 1379-1384, 2016.

KANBER, R.; KIRDA, C.; TEKİNEL, O. Irrigation water quality and salinity problems in ırrigation. Ç.Ü. Adana: Faculty of Agriculture General Publication, 1992. (Turkish).

KARA， A.; TUNÇTÜRK, M.; TUNÇTÜRK, R. Investigation of the effects on some physiological parameters of salt stress and seaweed applications in echinacea (Echinaceae purpurea L.) plant. Derim, v.36, n.2, 199-206, 2019. https://doi.org/10.16882/ derim.2019.537609.

KARRAY-BOURAOUIA, N.; RABHIB, M.; NEFFATI, M.; BALDAND, B.; RANIERİ, A.; MARZOUKC, B.; LACHAÂLA, M.; SMAOUIB, A. Salt effect on yield and composition of shoot essential oil and trichome morphology and density on leaves of Mentha pulegium. Industrial Crops and Products, v.30, 338-343, 2009.

KHAN, A.; SHAHEEN, Z.; NAWAZ, M. Amelioration of salt stress in wheat (Triticum aestivum L.) by foliar application of nitrogen and potassium. Science, Technology and Development, v.32, 85-98, 2013. 
KOZMINSKA, A.; AL HASSAN, M.; KUMAR, D.; OPRİCA, L.; MARTINELLİ, F.; GRİGORE, M.N.; BOSCAIU, M. Characterizing the effects of salt stress in Calendula officinalis L. Journal of Applied Botany and Food Quality, v.90, 323-329, 2017. https://doi. org/10.5073/JABFQ.2017.090.040

KUŞVURAN, Ş.;YAŞAR,F.;ABAK, K.;ELLİALTIOĞLU, Ş. CHANGES occur in lipid peroxidation, chlorophyll and 1on contents of some salt tolerant and sensitive Cucumis sp. genotypes grown under salinity stress. Yuzuncu Yil University Journal of Agricultural Sciences v.18, n.1, 13-20, 2008.

LARBİ, A.; KCHAOU, H.; GAALİCHE, B.; GARGOURİ, K.; BOULAL, H.; MORALES, F. Supplementary potassium and calcium improves salt tolerance in olive plants. Scientia Horticulturae, v.260, 108912, 2020. https://doi.org/10.1016/j.scienta.2019.108912

LAWSON, T. Guard cell photosynthesis and stomatal function. New Phytologist, v.181, 13-34, 2009. https://doi. org/10.1111/j.1469-8137.2008.02685.x

LEVENT TUNA, A.; KAYA, C.; ASHRAF, M.;ALTUNLU, H.; YOKAS, I.; YAGMUR, B. The effects of calcium sulphate on growth, membrane stability and nutrient uptake of tomato plants grown under salt stress. Environmental and Experimental Botany, v.59, n.2, 173-178, 2007.

LIU, S.; Lİ, X.; LARSEN, D.H.; ZHU, X.; SONG, F.; LIUU F. Drought priming at vegetative growth stage enhances nitrogen-use ef313. Plant, Soil and Environment, v.63, n.7, p.307-314, 2017. doi: 10.17221/287/2017-PSE

MALCOLM, C.V.; SMITH, S.T. Growing plants with salty water. Journal of the Department of Agriculture, Western Australia, v.3785, p.3-6, 1971.

MARSCHNER, P. Marschner's mineral nutrition of higher plants. 3rd edn. Waltham: Academic Press, 2012.

OZTURK, A. The effect of saline and normal waters applied in different stages on some properties of eggplant (Solanum melongena L.) and soil salinity. Journal of Agriculture Faculty of Selçuk University v.16, n.30, 14-20, 2002.

PATEL, P.; TRİPATHİ, A.; MAJHİ, B.; TRİPATHY, C.R. A new adaptive median filtering technique for removal of impulse noise from images. In: Proceedings of ACM International Conference on Communications, Computing and Securities. (ICCCS), 462-467, 2011.

PİNERO, M.C.; HOUDUSSE, F.; GARCİA-MINA, J.M.; GARNICA, M.; DEL AMOR, F.M. Regulation of hormonal responses of sweet pepper as affected by salinity and elevated $\mathrm{CO}_{2}$ concentration. Physiologia Plantarum, v.151, 375-389, 2014.
REEF, R.; LOVELOCK, C.E. Regulation of water balance in mangroves. Annals of Botany, v.115, n.3, 385-95, 2015.

REN, J.; LIU, Z.; DU, J.; FU, W.; HOU, A.; FENG, H. Finemapping of a gene for the lobed leaf, BoLl, in ornamental kale (Brassica oleracea L. var. acephala). Molecular Breeding, v.39, n.3, 40, 2019. https://doi.org/10.1007/ s11032-019-0944-0

SAJYAN, T.K.; SHABAN, N.; RİKALLAH, J.; SASSINE, Y.N. Performance of salt-stressed tomato crop as affected by nano-CACO 3, glycine betaine, mkp fertılizer and aspırın applicatıon. Poljoprivreda i Sumarstvo, v.65, n. 1, 19-27, 2019.

SHABALA, S.; POTTOSIN, I. Regulation of potassium transport in plants under hostile conditions: implications for abiotic and biotic stress tolerance. Physiologia Plantarum, v.151, n.3, 257-79, 2014.

TAÏBİ, K.; TAÏBİ, F.; ABDERRAHIM, L.A.; ENNAJAH, A.; BELKHODJA, M.; MULET, J.M. Effect of salt stress on growth, chlorophyll content, lipid peroxidation and antioxidant defence systems in Phaseolus vulgaris L. South African Journal of Botany, v.105, 306-312, 2016.

TANVEER, K.; GILANI, S.; HUSSAİN, Z.; ISHAQ, R.; ADEEL, M.; ILYAS, N. Effect of salt stress on tomato plant and the role of calcium. Journal of Plant Nutrition, v.43, n.1, 28-35, 2020. https://doi.org/10.1080/01904167.2 019.1659324

TURAN, M.; AYDIN, A. Effects of different salt sources on growth, inorganic ions and proline accumulation in corn (Zea mays L). European Journal of Horticultural Science, v.70, 149-155, 2005.

TÜRKMEN, Ö.; ŞENSOY, S.; ERDAL, İ.; KABAY, T. Effects of calcium on the emergence and seedling growth of tomatoes grown in salty growing media conditions. Yuzuncu Yil University Journal of Agricultural Sciences, v.12, n.2, 53-57, 2002.

XU, C.; MOU, B. Responses of spinach to salinity and nutrient deficiency in growth, physiology, and nutritional value. Journal of the American Society for Horticultural Science, v.141, n.1, 12-21, 2016. https://doi.org/10.21273/ JASHS.141.1.12

YADAV, S.P.; BHARADWAJ, R.; NAYAK, H.; MAHTO, R.; SINGH, R.K.; PRASAD, S.K. Impact of salt stress on growth, productivity and physicochemical properties of plants: A Review. International Journal of Chemical Studies, v.7, n.2, 1793-1798, 2019.

YAKIT, S.; TUNA, A.L. Tuz stresi altındaki mısır bitkisinde (Zea mays L.) stres parametreleri üzerine $\mathrm{Ca}$, $\mathrm{Mg}$ ve K'nın etkileri. Journal of Agriculture Faculty of Akdeniz University, v.19, n.1, 59-67, 2006. 
YİLDIZ, M.; TERZİ, H. Determination of early seedling stage salt tolerance in some barley cultivars grown in Turkey. Journal of Agricultural Sciences, v.17, n.1, 1-9, 2011.

YU, X.; FEİ, P.; XİE, Z.; ZHANG, W.; ZHAO, Q.; ZHANG, $\mathrm{X}$. Effects of methyl jasmonate on growth, antioxidants, and carbon and nitrogen metabolism of Glycyrrhiza uralensis under salt stress. Biologia plantarum, v.63, n.1, 89-96, 2019. https://doi.org/10.32615/bp.2019.011
ZHU, X.; CAO, Q.; SUN, L.; YANG, X.; YANG, W.; ZHANG, H. Stomatal conductance and morphology of arbuscular mycorrhizal wheat plants response to elevated $\mathrm{CO}_{2}$ and $\mathrm{NaCl}$ stress. Frontiers in Plant Science, v.9, 2018.

ZİREK, N.S.; UZAL Ö. The developmental and metabolic effects of different magnesium dozes in pepper plants under salt stress. Notulae Botanicae Horti Agrobotanici Cluj-Napoca, v.48, n.2, 967-977, 2020. https://doi. org/10.15835/nbha48211943 